\title{
Evaluation and Release of High Yielding and High Oil Containing Mustard for Terai and Inner Terai of Nepal
}

\author{
Bisheswar Prasad Yadav*1, Santosh Rasaily ${ }^{1}$, Pramod Wagle ${ }^{1}$, Razan Malla ${ }^{1}$, Manoj Kandel ${ }^{1}$, \\ Nabina B.K. ${ }^{2}$, Sheetal Aryal ${ }^{3}$
}

${ }^{1}$ Nepal Agricultural Research Council, Nepal

${ }^{2}$ Mahadev Janata Higher Secondary School, Nepal

${ }^{3}$ Cimmyt International, Nepal.

\begin{abstract}
Article Information
Received: 20 November 2020

Revised version received: 23 December 2020

Accepted: 25 December 2020

Published: 28 December 2020

Cite this article as:

B.P. Yadav et al. (2020) Int. J. Appl. Sci. Biotechnol. Vol 8(4): 454-456. DOI: 10.3126/ijasbt.v8i4.33825

*Corresponding author

Bisheswar Prasad Yadav,

Nepal Agricultural Research Council, Nepal

Email: masteryadavbp2001@gmail.com

Peer reviewed under authority of IJASBT

(C) 2020 International Journal of Applied Sciences and Biotechnology
\end{abstract}

\section{OPEN 0 ACCESS}

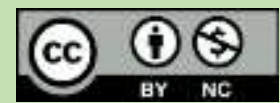

This is an open access article $\&$ it is licensed under a Creative Commons Attribution Non-Commercial 4.0 International (https://creativecommons.org/licenses/by-nc/4.0/)

Keywords: high yielding; protein content; CVT; CFFT; Release

\begin{abstract}
In Recent years, cultivation of Mustard (Brassica juncea) is growing popularity but there is lack of suitable high yielding and oil contenting variety in Nepal. With Objective of identifying and releasing of high yielding variety, evaluation of exotic genotypes were done in the research field and farmers field. Coordinated Varietal Trial (CVT) was conducted for three years in three different location (Nawalpur, parwanipur and Khajura) in RCBD design. 4 Elite genotypes were selected and further evaluate under Coordinated Farmer Field Trial (CFFT) for 5 years where each farmer was considered as Replication. Nutrients Analysis was done to find out the moisture, oil and protein content of selected elite genotypes. In combined ANNOVA of CVT, ICJ 9704 was found to be high yielding genotypes. Similarly, In CFFT, genotypes was significantly for yield where ICJ 9704 produced highest yield $(906.75 \mathrm{~kg} / \mathrm{ha})$ where as Divya, Pusa Jagarnath and Krishna produced yield of $798.12 \mathrm{~kg} / \mathrm{ha}, 790 \mathrm{~kg} / \mathrm{ha}$ and $767.392 \mathrm{~kg} / \mathrm{ha}$. ICJ 9704 has high oil content 37.3 $\%$ with $36.3 \%$ protein content. In 2017, ICJ 9704 was release as Morang rayo and was recommended to grow in the terai and inner terai. Hope this variety will be popular among mustard growing farmer and will help to meet the national demand of the Nation.
\end{abstract}

\section{Introduction}

Mustard (Brassica juncea) also called as rayo/ raichi/ tora is most potential winter oilseed crop of Nepal. It is gaining popularity day by day and as compared to previous year, its area and production is in increasing trend. The area under mustard (Rayo) cultivation in Nepal was 3879 ha, production $3843 \mathrm{mt}$ and productivity $0.990 \mathrm{mt} / \mathrm{ha}$ (MoALD, 2019) but substantial amount of acreage has been found under mixed cropping with wheat, lentil, chickpea and linseed (Ghimire et al., 2000). Two varieties of mustard namely, Krishna and Pusa Bold have been released for general cultivation in irrigated as well as in rainfed condition. The limited numbers of varieties and increasing cultivated are of mustard year by year shows that there is indispensable need of better breeding technique and better screening techniques to increase the yield potential of this crop. The unavailability of high yielding varieties may be 
one of the causes of low yield. On the other hand, very limited genetic stock with narrow genetic base is available at our condition. Improvement of Brassica juncea has mostly been confined to the exploitation of the naturally occurring genetic variability in the cultivated species. Brassica juncea commonly cultivated in Indian subcontinent has limited variability left for direct selection for higher seed yield (Kumar \& Singh, 1998). Keeping these points in view, to select and release high yielding lines of mustard, series of trials like Coordinated varietal trials (CVT) and Coordinated Farmers Field Trial (CFFT) were conducted at NORP, Nawalpur, RARS, Parwanipur and RARS, Nepalganj in various year (ORP- Annual Report 2013/14, 2014/15,2015/16).

\section{Materials and Methods}

14 Local and Exotic germplasm selected from Observation nursery and Initial Yield trails were evaluated in Coordinated varietal trial under different environment condition of Nepal (Oil Seed Research Program, Sarlahi, Regional agriculture Research Station, Parwanipur, Regional Agricultural Research Station, Khajura,) in 3 different on succeeding year, 2014, 2015 and 2016. Coordinated Varietal Trial was conducted in Random Complete Block Design (RCBD) with 14 Genotypes including local genotypes in 3 replications with the plot size of $5 * 2.1 \mathrm{~m}^{2}$. Among the 14 genotypes, 4 genotypes were selected for Coordinated Farmer field Trials in the same location in 2015, 2016, 2017 A.D (ORP-Annual Report 2014/15, 2015/16, 2016/17) with plot size of $50 \mathrm{~m}^{2}$ were each farmer was considered as Replication. Chemical fertilizers were applied @ 60:40:20 kg/ha. Similarly, nutrient analysis (moisture, fat and protein content) was done in National Food Technology Research Centre, Narc. Computer based Statistical software like Crop stat and ADEL-R was used to analyze the data.

\section{Results and Discussion}

Different analysis like ANOVA of CVT and CFFT and nutrient analysis was done to find the best Mustard variety for the wider range of Nepal. In combined ANOVA CVT of 3 year, For the yield, genotype was highly significant ( $p$ value $=0.007)$ to each other, location was not significant $(p$ value $=0.12$ ) and genotype and environment interaction was also not significant ( $\mathrm{p}=0.12$ ). Among 14 genotypes, ICJ 9704 has highest yield with $1146.589 \mathrm{~kg} / \mathrm{ha}$ whereas ICJ 01 40 has lowest yield which measure $695 \mathrm{~kg} / \mathrm{ha}$.

In CFFT, there was high significant difference ( $\mathrm{p}$ value= 0.0033 ) in yield among the four elites selected genotypes. ICJ 9704 was consider to be highest yielding with the yield of $906.123 \mathrm{~kg} / \mathrm{ha}$ in farmer field condition followed by Divay (798.127 kg/ha), Pusa jagarnath ( $790.007 \mathrm{~kg} / \mathrm{ha}$ ) and Krishna ( $767.392 \mathrm{~kg} / \mathrm{ha}$ ) which is show in table no.

Simially, in Nutrient analysis, the result showed ICJ 9704 with low moisture content $(7.62 \%)$ and with high fat content
(37.3\%) among the selected elite genotypes. Simialry, the nutrient analysis showed that ICJ 9704 has 36.3 protein content. From the all the test, ICJ 9704 was considered to be highest yielding genotypes with high oil content among the tested genotypes.

Table 1: ANOVA table of Coordinated Variety Trials (CVT)

\begin{tabular}{|l|l|}
\hline Genotypes & Yield (kg/ha) \\
\hline ICJ 9704 & 1146.589 \\
\hline ICJ 9701 & 899.5222 \\
\hline RH 30 & 882.0667 \\
\hline PusaJaganath & 873.6667 \\
\hline Rohini & 860.9556 \\
\hline RH 811-3 & 831.0444 \\
\hline ICJ 01-62 & 785.5556 \\
\hline PusaAgarani & 774.0778 \\
\hline ICJ 9708 & 763.5556 \\
\hline ICJ 01-11 & 758.5556 \\
\hline T 59 & 751.8889 \\
\hline Krishna & 733.7 \\
\hline ICJ 01-56 & 711.4444 \\
\hline ICJ 01-40 & 695.1111 \\
\hline Grand Mean & 819.12 \\
\hline CV & 26.88 \\
\hline LSD & 205.67 \\
\hline P Value (Genotype) & NS (0.000791) \\
\hline P Value (Environmnet) & \\
\hline P value(G*E) & \\
\hline
\end{tabular}

Table 2: ANNOVA of Coordinated Farmers Field Trial (CFFT)

\begin{tabular}{|l|l|}
\hline Genotypes & Yield \\
\hline ICJ 9704 & 906.755 a \\
\hline Divya & 798.127 \\
\hline PusaJaganath & 790.007 \\
\hline Krishna & 767.392 \\
\hline GRAND MEAN & 815.57 \\
\hline LSD & 74.78 \\
\hline P $(0.05)$ & $* *(0.0033)$ \\
\hline CV & 9.9 \\
\hline
\end{tabular}


Table 3: Nutrient analysis of mustard

\begin{tabular}{|l|l|l|l|l|}
\hline T.N. & Varieties & Moisture & Fat (Oil) & Prote \\
\hline 1 & ICJ 9704 & 7.62 & 37.3 & in \\
\hline 2 & Divya & 8.01 & 37 & 37.8 \\
\hline 3 & PusaJagannath & 7.43 & 37.1 & 36.3 \\
\hline
\end{tabular}

\section{Conclusion}

In context to Nepal, there is lack of manpower, technology and faculties to generate the new genotypes. To find the new promising varieties suitable for Nepal, testing of the exotic genotypes is the best way of the time being. With the result of continuous trial for 12 years (Observation nursery, Initial yield Trial, Coordinated farmers Field Trial, Coordinated varietal trail, ) Proposal was present in Seed Quality Control Centre ( SQCC) to release ICJ 9704 as a variety. Finally, In 2017, ICJ 9704 was release as Morang Rayo inheriting the potential of high yield with high amount of oil content and protein.

\section{Author's Contribution}

All authors contributed equally in the all stages of research works, manuscript preparation and finalization.

\section{Conflict of Interest}

The authors declare that there is no conflict of interest with present publication.

\section{Acknowledgment}

Authors acknowledge Nepal Agricultural Research Council, Singha Durbar Plaza, Bagmati Province, Nepal; Oil Seed Research Progrm, Nawalpur, Sarlahi, Province no 2, NARC, Nepal; Agricultural Research Directorate, Parwanipur, Bara, Province no 2, NARC, Nepal \& Agricultural Research Directorate, Khajura, Nepalgunj
Province no 5, NARC, Nepal for their supports in many ways for this research work.

\section{References}

Ghimire TB, Chaudhary RN and Ray SP (2000) Quantification of yield limiting constraints in toria production. Annual report, NORP, 2000/2001. 61p.

Kumar A and Singh D P (1998) Use of physiological indices as ascreening technique for drought tolerance in oil seeds Brassica species. Annals of Botany 81: 413-412. DOI: $\underline{10.1006 / \text { anbo.1997.0573 }}$

MoALD (2019) Statistical Information on Nepalese Agriculture, 2017/18. Ministry of Agriculture and Livestock Development, Agri-Business Promotion and Statistics Division, Sighdurbar, Kathmandu, Nepal.

ORP (2014) Coordinated Farmers Field Trial, Rayo. In: Annual Report 2070/71 (2013/14) Oilseed Research Program, NARC, Nawalpur, Sarlahi, , Nepal. 62-63p.

ORP (2014) Coordinated Varietal Trial,Rayo. In:Annual Report 2070/71 (2013/14).Oilseed Research Program, NARC, Nawalpur, Sarlahi, , Nepal. 31-33 p.

ORP (2015) Coordinated Farmers Field Trial, Rayo. IN: Annual Report 2071/72 (2014/15) Oilseed Research Program, NARC, Nawalpur, Sarlahi, , Nepal. 65-66p.

ORP (2016) Coordinated Farmers Field Trial, Rayo. IN: Annual Report 2072/73(2015/16) Oilseed Research Program, NARC, Nawalpur, Sarlahi, Nepal.57-58 p.

ORP (2016) Coordinated Varietal Trial, Rayo. IN: Annual Report 2072/73(2015/16) Oilseed Research Program, NARC, Nawalpur, Sarlahi, Nepal.30-34 p.

ORP (2017) Coordinated Farmers Field Trial, Rayo. In: Annual Report 2073/74(2016/17).Oilseed Research Program, NARC, Nawalpur, Sarlahi, Nepal. 69 p.

ORP (2017) Coordinated Varietal Trial, Rayo. In: Annual Report 2073/74(2016/17). Oilseed Research Program, NARC, Nawalpur, Sarlahi, Nepal. 46-48 p. 